\title{
SKIRTINGŲ PROFILIŲ SVEIKATOS PRIEŽIŪROS SPECIALISTŲ POŽIŪRIS İ KINEZITERAPIJĄ
}

\author{
Evelina Ašmontaitė, Margarita Radžiūnienė \\ Lietuvos sveikatos moksly universiteto Medicinos akademijos Slaugos fakultetas, Sporto institutas
}

Raktažodžiai: odontologija, fizinė medicina ir reabilitacija, šeimos medicina, ortopedija - traumatologija, kineziterapeutas.

\section{Santrauka}

Tyrimo tikslas - ištirti skirtingų profilių sveikatos priežiūros specialistų požiūrị ị kineziterapiją. Tyrimo klausimas: kokia skirtingų profilių sveikatos priežiūros specialistų nuomonè apie kineziterapiją ? Tyrimo metodika. Darbe taikytas kokybinis tyrimo metodas. Tyrimo duomenims rinkti pasirinktas buvo individualaus interviu metodas. Atliekant interviu tyrimo dalyviams buvo pateiktas klausimynas, sudarytas iš 16 klausimų.

Tiriamieji. Tyrime dalyvavo 20 tiriamujų -5 fizinès medicinos ir reabilitacijos gydytojai, 5 šeimos gydytojai, 5 odontologai ir 5 ortopedai - traumatologai. Tyrime dalyvavo sveikatos priežiūros specialistai, savanoriškai sutikę atsakyti i pateiktus klausimus.

Išvados. Tyrime dalyvavusių sveikatos priežiūros specialistų nuomoné buvo vieninga: kineziterapija yra gydymas judesiu. Kineziterapeuto veiklą skirtingi sveikatos priežiūros specialistai ịvardija ne vienodai: atlieka mankštą, kurią paskiria fizinès medicinos ir reabilitacijos gydytojas ar kineziterapeutas, ištiria ir įvertina pacientą ir pats sudaro individualią programą bei ją koreguoja gydymo procese, nustato kineziterapijos diagnozę ar stebi paciento atliekamus pratimus, konsultuoja sveikos gyvensenos klausimais. Apklausti sveikatos priežiūros specialistai įvardija akivaizdų neatitikimą tarp gerai dirbančių ir ruošiamų kineziterapeutų skaičių - gerų specialistų didelis trūkumas. Ne mažai apklaustų sveikatos priežiūros specialistų kineziterapeuto atliekamą darbą ịvardijo kaip pagalbinę gydymo priemonę.

\section{Ivadas}

Kineziterapija - vis labiau populiarèjanti gydymo sritis Lietuvoje. Tačiau vis dar nèra nusistovejjusios visuomenès nuomonès, kas tai yra. Vienų žmonių teigimu, tai tiesiog pagalbinè priemonè prie skiriamo gydymo, tačiau naujoji 2016 metais Lietuvos Respublikos sveikatos apsaugos ministerijos priimta kineziterapijos norma teigia, kad tai gydymas, turintis teorinị ir praktinį pagrindą bei platų klinikinį pritaikymą ligų ir traumų prevencijai [1]. Lietuvos aukštujų mokyklų asociacijos bendrajam priemimui organizuoti (LAMA BPO) duomenimis, kasmet i Lietuvos aukštąsias neuniversitetines mokyklas pirmu pageidavimu prašymą studijuoti kineziterapijos studijose pateikia apie 200 studentų, o ị aukštąsias universitetines mokyklas apie 40 studentų. Tai viena iš gausiausiai ruošiamų specialybių aukštosiose universitetinèse ir neuniversitetinèse mokyklose. Atsižvelgiant ị gausų kineziterapeutų ruošimą Lietuvoje, mūsų darbu norèta išsiaiškinti skirtingų sveikatos priežiūros specialistų požiūrị ị kineziterapiją.

Per metus Lietuvoje paruošiama apie 500 kineziterapeutų, ši specialybė tampa vis populiaresnè, tačiau kaip kineziterapeutų darbą vertina sveikatos priežiūros specialistai, dirbantys tiek vienoje komandoje su kineziterapeutais, tiek atitolusių specialybių, taip ir nežinome.

Lietuvos ir užsienio mokslininkų darbuose plačiai nagrinejjami kineziterapijos metodai bei jų efektyvumas, analizuojami kineziterapeutu rengimo klausimai, kineziterapeutu pasitenkinimas darbo sąlygomis, kineziterapijos paslaugų kokybė, tačiau pasigendama pačios kineziterapijos, jos poreikio ir kineziterapeuto darbo vertinimo. Pavyko rasti tik keletą straipsnių, kurie išsamiau nagrinètų kineziterapeutų profesinį savarankiškumą, paslaugų licencijavimo bei privačios veiklos klausimus, kineziterapeutų bendradarbiavimą su kitais specialistais. Taip pat nepavyko rasti atlikto kokybinio tyrimo šia tema Lietuvoje. Skirtingų sveikatos priežiūros specialistų požiūris ị kineziterapiją nèra aiškiai susiformavęs Lietuvoje ir mokslinių darbų šia 
tema stoka rodo šio darbo temos naujumą.

Tyrimo tikslas - ištirti skirtingų profilių sveikatos priežiūros specialistų požiūrị ị kineziterapiją.

\section{Tyrimo objektas ir metodika}

Tyrimo duomenims rinkti pasirinktas individualaus interviu metodas. Taikant pasirinktą metodą tyrèjas yra dèmesingas klausytojas [2]. Tyrejo užduotis - skatinti kuo daugiau išsipasakoti tiriamaji, bet ne pačiam dalintis savo patirtimi ar padèti atsakyti ị klausimus. Šiuo interviu metodu buvo siekiama gauti kuo daugiau informacijos, kuri padètų ịvertinti skirtingų sveikatos priežiūros specialistų požiūrị ị kineziterapiją.

\section{Rezultatai ir jų aptarimas}

Tyrime dalyvavę sveikatos priežiūros specialistai teigè, kad kineziterapija, tai gydymas judesiu, mankštomis, tam tikra judesių terapija, mokslas, fiziniai veiksniai. Kai kuriems ortopedijos-traumatologijos (ORT) specialistams kilo klausimas, ar galima kineziterapiją ir ergoterapiją suvienodinti ir pateikiant kineziterapijos apibrežimą ịtraukti smulkiosios motorikos lavinimą: „O ergoterapija ir kineziterapija čia kažkuo skiriasi?”, - klausė ORT specialistas. Tiriamieji kineziterapijos savoką apibūdino trumpai ir aiškiai, nei vienas neišsiplète ir nesistengè pateikti plataus apibrěžimo. Tik vienas iš tiriamuju, šeimos medicinos (ŠM specialistas, kineziterapiją ịvardijo kaip vieną pagrindinių reabilitacijos sričių: „Kineziterapija - tai gydymas judesiu, viena iš reabilitacijos sričių, realiai pagrindiné."

Paklausus apie kineziterapeutų atliekamą darbą gydytojų nuomonès bei žinios išsiskyrẻ ir kineziterapeuto darbą apibūdino dvejopai. Fizinès medicinos ir reabilitacijos (FRM) specialistai ir ORT specialistai teigè, jog kineziterapeutai ištiria ir įvertina paciento būklę, nustato kineziterapijos diagnozę, sudaro ir pritaiko individualią pratimų programą, pasak FMR specialisto: „Visu pirma, kineziterapeutas diagnozuoja esančias problemas, raumenu tonuso pakitimus, judesių apribojimus, skausmingus taškus ir pan. Tuomet pritaiko tinkamą gydymą ar tiesiog stiprinimą, tai gali būti mankštų pagalba, masažu ar ịvairių pratimų. Taip pat jis seka progresą bei pakitimus." Visiškai kitoki kineziterapeuto darbą apibrežè ŠM ir odontologijos (OD) specialistai. Jie teigè, jog kineziterapeutas tik padeda atlikti pratimus, veda grupines mankštas ar tiesiog tik stebi sporto klube sportuojančius žmones, kad jie nepasidarytų sau žalos bei dalija sveikos gyvensenos patarimus, anot OD specialisto: „Kineziterapeutas koreaguoja atliekamus judesius, konsultuoja bei rūpinasi pacientų sveika gyvensena, prižiūri žmones, sportuojančius sporto klube." Pasak E. Cromie, M. Grant, L. Oldmeadow ir V. Robertson, kineziterapeutu atliekamas darbas labai priklauso nuo aplinkos, kurioje jis dirba, pavyzdžiui, ar tai privati praktika, ar darbas paciento namuose, ar viešojoje ịstaigoje [3].

I kineziterapeutų kompetencijas ir jų darbo galimybes sveikatos priežiūros specialistai pažvelgè labai skirtingai. OD specialistai nežinojo, ką kineziterapeutas iš tikrujų gali atlikti, ŠM specialistai akcentavo mankštas, rūpinimąsi griaučių - raumenų sistema. Tačiau buvo ir nuomonių, kurios pabrèžè, jog visas kineziterapeuto darbas priklauso nuo fizinès medicinos ir reabilitacijos gydytojo nurodymų, jo suformuluotų tikslų bei rekomendacijų, pasak FMR specialisto: „Kineziterapeuto visas darbas turètų priklausyti nuo reabilitologo, jo nurodymų, pastebėjimų ir rekomendacijų." Reabilitacijos procese vyksta komandinis darbas, kiekvienas dalijasi savais pastebejimais, tiria ir vertina pacientą, renka anamnezę. Nèra taip, kad vieno specialisto darbas priklausytų nuo kito. FRM gydytojas - komandos vadovas, nes jis tarsi suburia visą komandą, pats pirmas pastebi, kur reiktų vienokios ar kitokios pagalbos, tačiau gydymo procese vyksta komandinis darbas [4]. Taip pat buvo nuomonių, kurios teige, kad kineziterapeuto kompetencijų norma labai ịdomi ir nuolat kintanti, todèl negalèjo atsakyti, kokios būtent šių specialistų kompetencijos. Tačiau ši norma nèra nuolat kintati, nes 2004-ujjų metų norma atnaujinta tik po 12 metų - 2016 taisiais [1]. Ar šių kompetencijų gana, nuomonès išsiskyrè. Viena: kompetencijos yra įstatymiškai reglamentuotos, todèl jų turi užtekti ir tikrai nereikia plèsti, o kita nuomonè: kineziterapeutas turètų mokèti atlikti tam tikras raumenų elektros stimuliacijos procedūras, magneto ir kitas terapijas, daugiau paciento testavimo. Kineziterapeutų normoje rašoma, jog specialistas turi gebeti taikyti ivvairius fizikinius veiksnius, tokius kaip elektros terapiją, šalčio terapiją, magneto terapiją, šviesos terapiją [1]. Atsirado ižvalgų, kad norint būti geru kineziterapijos specialistu, reiktu palankyti psichologijos kursus, nes norint atstatyti paciento griaučiu - raumenų sistemą labai svarbu ji palaikyti psichologiškai: „Manau, kad kineziterapeutas turetų būti ir geras psichologas, kad motyvuotų, palaikytų pacientą, nes dažnai žmogus po patirtos nelaimès nebetiki, kad galès vèl gyventi kaip anksčiau ir nenori keltis iš lovos, judèti, stengtis," - teigè OD specialistas. Norètume pastebėti, kad psichologų konsultacijų reiktų visiems sveikatos priežiūros specialistams, nes darbas su žmonemis visada reikalauja psichologinių žinių. Mokymo ịstaigose ruošiant kineziterapeutus yra ir psichologijos kursas. Tačiau kineziterapeuto normoje kompetencijų skiltyje nèra rašoma apie psichologo konsultacijas. Visada pacientui patekus ị gydymo įstaigą sudaromas specialistų sąrašas, kas turètų dirbti su pacientu. Dažniausiai, sunkesniais atvejais, pavyzdžiui, kai pacientas nemotyvuotas, ị gydytojų komandą yra įtrau- 
kiamas ir psichologas [5].

Kineziterapija kaip specialybè šiuo metu labai paklausi ir reikalinga, tai pabrèžè ir tyrime dalyvavę sveikatos priežiūros specialistai. Tiriamieji vienareikšmiškai atsakè, jog kineziterapeuto specialybė reikalinga, kai kurie net pabrèžè, jog labai reikalinga ir nekyla jokių abejonių. Tačiau uždavus klausimą, ar šiuos specialistus gali pakeisti kažkas kitas, išsiskyrè nuomonès. Vieni pasisakè, jog kineziterapeuto niekas negali pakeisti, anot OD specialisto: „Kol kas nėra tokių specialistų, kurie būtų taip ịsigilinę ị visą kūno biomechaniką ir ją galètų taikyti." Kiti teigè, jog fizinès medicinos ir reabilitacijos specialybė yra artima kineziterapijai ir galbūt praplètus rezidentūros studijų programą, kineziterapeutus pakeistų būtent šios srities specialistai; pasak FMR specialisto: „Praplètus reabilitologų (aut. pastaba: fizinès medicinos ir reabilitacijos gydytojų) profili ir mokymosi programą, jie galètų pakeisti kineziterapeutus." Tačiau kyla klausimas, ar tuomet nebūtų per daug užkrauta ant fizinès medicinos ir reabilitacijos gydytojų pečių? Tuomet tiesiog atsirastų specialistų, kurie išmano viską, tačiau labai siaurai ir nèra ịsigilinę ị tam tikras problemas. Pasak E. Cromie, M. Grant, L. Oldmeadow ir V. Robertson, fizinès medicinos ir reabilitacijos gydytojai galètu pakeisti kineziterapeutus, jeigu jie būtų labiau ịsigilinę ì pratimų programos sudarymą, kineziterapijos priemones ir žmogaus biomechaniką; tačiau šios srities gydytojai labiau specializuojasi ị paciento ištyrimą ir tinkamų reabilitacijos priemonių parinkimą [3]. S. Mathur teigia, jog kineziterapija vis labiau populiarejanti specialybe ir jai reikalingas isitvirtinimas sveikatos sistemoje. Todèl Amerikos kineziterapijos asociacija $2020 \mathrm{~m}$. ruošiasi ịsteigti naują studijų programą, kurią baigus kineziterapeutas taptų savarankišku gydytoju [6].

Kineziterapija padeda žmogui, teigè tyrime dalyvavę sveikatos priežiūros specialistai. Tačiau išsiskyrẻ keletas nuomonių, jog labai daug kas priklauso ir nuo paties paciento, jo motyvacijos ir pastangų: „Jei pats žmogus motyvuotas, tai kineziterapija visada padeda," - sake FMR specialistas. Be to, kai kurie pabrèžè ir specialisto dedamas pastangas padèti pacientui, jo domèjimąsi, gilinimąsi ị problemas. Taip pat buvo atsižvelgta, jog kineziterapeutas turètų gerai išmanyti savo darbą, jausti meilę darbui, domètis savo profesija, nes tik tuo atveju jis sugebès tinkamai padèti žmogui, kitaip tai tik bus neprofesionalus darbas, pasak OD specialisto: „Kineziterapija neabejotinai padeda žmogui, bet tik tuo atveju, jei patenki pas gerą specialistą."

Kalbedami apie kineziterapeutų atliekamą darbą tyrime dalyvavę sveikatos priežiūros specialistai įžvelgè trūkumų. Vieni akcentavo, kad labiausiai trūksta reklamos ir informavimo apie šią specialybę, nes dauguma žmonių netiki procedūrų efektyvumu: „Trūksta informacijos apie efektyvumą jūsų veiklos, kai kurie pacientai pakankamai skeptiškai žiūri i šias procedūras ir tik po jų pakeičia nuomonę", - teigè ŠM specialistas. Kiti sakè, jog didžiausias trūkumas yra menkas ligonių kasų finansavimas, pacientai nemokamai gauna vos keletą procedūrų, ir tai neteikia jokios naudos. Taip pat pastebèta, jog kineziterapeutams trūksta priemonių bei patalpu jų ergonomiškam darbui, anot ORT specialisto: „Šiaip yra didelis stygius priemonių ir tai juodoji kineziterapijos pusè, nes dažnu atveju jūsų darbo vieta nèra ergonomiška." Be to, buvo išsakytos ir pastabos, jog kineziterapeutų darbui trūksta kokybės, nes daug kas atlieka „klasikinę fizkultūrą”, o ne individualiai pritaikytą kineziterapiją. Pastebèta, jog kineziterapeutams trūksta kompetencijos, anot FMR specialisto: „...Aš einu pasikonsultuoti pas kineziterapeutą, bet ir iš jo negaunu tvirto, o kartais jokio atsakymo... Jei jau esi kineziterapeutas, tai ir turi virti tose sultyse, ir domètis savo specialybe." Kineziterapeuto kompetenciją sudaro žinios, gebẻjimai ir įgūdžiai, kuriuos specialistas igyja baigdamas kvalifikaciją suteikiančias studijas [1]. Kompetencijų sąrašas labai platus, todèl iš viso to didelio sąrašo specialistai, turbūt, negeba jų visų ịsisavinti. Taip pat trūksta gebejjimo motyvuoti ir prieinamumo, nes kai kurie pacientai turi laukti keletą mènesių, kad galètų pakliūti pas kineziterapeutą: „Trūksta prieinamumo, ne visi pacientai gali pakliūti pas kineziterapeutą," - teige ŠMM specialistas. Privačiose klinikose pacientai pas kineziterapeutą patenka daug greičiau, nes eilès daug mažesnès, tačiau ne visi pacientai gali susimokèti, todèl renkasi viešąsias gydymo ịstaigas. Susidaro situacija, kai viešosiose ịstaigose pacientai vien kineziterapeuto konsultacijos laukia pora ménesių. Stacionaro pacientai, jeigu yra reikalinga kineziterapija, ją jau gauna pirmosiomis stacionarizavimo paromis, ir ji tęsiama iki išrašymo [7]. Norètume atkreipti dèmesi, kad kineziterapijos kvalifikaciją per metus Lietuvoje igyja apie 500 žmonių, tačiau darbo vietų per metus vidutiniškai (darbo biržos duomenimis) atsiranda tik šimtui. Poreikis yra didelis, bet nèra darbo vietų, daugelis kineziterapeutu nori dirbti privačiai, bet ịstatyminè bazè yra sudètinga, kad būtu galima dirbti legaliai.

\section{Išvados}

1. Tyrime dalyvavusių sveikatos priežiūros specialistų nuomonè buvo vieninga: kineziterapija yra gydymas judesiu, ji reikalinga ir naudinga visuomenei. Dél kompetencijų ir kineziterapeuto darbo apklaustų specialistų nuomonè išsiskyre: vieni teige, kad kineziterapeuto darbas apima mažai pareigų (negali atlikti masažo ir ne visas fizioterapijos procedūras), kiti teige - daug, nes kineziterapeutas gali dirbti tiek sveikatos priežiūros ịstaigose, reabilitacijos 
centruose, tiek sporto klube ar sveikatingumo srityje. Kineziterapeuto veiklą skirtingi sveikatos priežiūros specialistai ịvardija nevienodai: atlieka mankštą, kurią paskiria fizinès medicinos ir reabilitacijos gydytojai ar kineziterapeutas, ištiria ir ịvertina pacientą ir pats sudaro individualią programą bei ją koreguoja gydymo procese, nustato kineziterapijos diagnozę ar stebi paciento atliekamus pratimus, konsultuoja sveikos gyvensenos klausimais. Vis dèlto ne visi apklausti sveikatos priežiūros specialistai skiria, kas yra kineziterapeutas, ergoterapeutas, treneris ar masažuotojas.

\section{Literatūra}

1. Lietuvos medicinos norma MN 124:2016 „Kineziterapeutas. Teise, pareigos, kompetencijos ir atsakomybe்". LR SAM [Internet] [paskelbta 2016] [žiūrèta 2016 spalio 3d.]. Prieiga per internetą: https://www.e-tar.lt/portal/lt/legalAct/74aed040cf3 811e583a295d9366c7ab3

2. Butkevičienė R., Klemmac D., Vaškelyte A. Neišnešiotu naujagimių, gydomų Naujagimių intensyvios terapijos skyriuje, tèvų poreikiai. Kaunas: Medicina, 2009; 45 (4): 320 - 326.

3. Crome E, Grant M, Oldmeadow L, Robertson V. Taking charge of change: a new career structure in physiotherapy. Australian Journal of Physiotherapy 2003; 49 (4): $229-231$. https://doi.org/10.1016/S0004-9514(14)60138-0

4. Angoules A, Lewis C, Rosner A. Physiotherapy and physical rehabilitation. Journal of Physiotherapy \& Physical Rehabilitation 2017; 14: $1-3$.

5. World health organization. Disabilities and rehabilitation [Internet] [paskelbta 2011 vasario 15 d.] [žiūrèta 2016 gruodžio 29d.]. Prieiga per internetą:http://www.who.int/disabilities/ world_report/2011/chapter4.pdf

6. Mathur S. Doctorate in physical therapy: is it time for a conversation? Physiother Can 2011; 63(2): 140-142.

https://doi.org/10.3138/physio.63.2.140

7. Dèl medicininès reabilitacijos ir sanatorinio (antirecidyvinio) gydymo organizavimo. Lietuvos Respublikos sveikatos apsaugos ministras. $2008 \mathrm{~m}$. sausio 17d. İsakymas Nr. V- 50. Valstybės žinios, Nr. 12-407 [Internet] [paskelbta 2008 sausio 17 d.][žiūrèta 2017 sausio 27 d.]. Prieiga per internetą: https:// www.e-tar.lt/portal/lt/legalAct/TAR.528500FDBAEE

\section{DIFFERENT HEALTH CARE PROFESSIONALS APPROACH TO PHYSICAL THERAPY}

\section{E. Ašmontaitė, M. Radžiūnienè}

Key words: odontology, family medicine, physical medicine, orthopedics - traumatology, physiotherapists.

Summary

The aim - research different health care professionals approach to physical therapy.

Question. What is the opinion of different health care professionals about physiotherapy and physical therapist job?

Methodology. In this study qualitative researches method was used. The research data collection was selected by individual interview method. During the interview the study participants were given questionnaire consisting of 16 questions.

Participants. 20 subjects participated in the research -5 physical medicine and rehabilitation doctors, 5 family doctors, 5 dentists and 5 orthopedists - traumatologists. Participated health care professionals agreed to answer the questions voluntarily.

Conclusion. The opinion of health care professionals was unanimous, that physical therapy is the treatment of movement, it is necessary and useful to the public. On the competence and physical therapist working professionals opinion was different: some argued that the physical therapist job involves little functions (can't perform massage and physiotherapy procedures at all) others said many of physical therapists can work in both health care facilities, rehabilitation centers, in the gym or a health field. The description of physical therapists activities different health care professionals had differed: performing exercises, prescribing physical medicine and rehabilitation physicians or physical therapist, examining and evaluating the patient and suitable invidual program adjusting the treatment process, providing physiotherapy diagnosis or watching patients performing exercises, giving advice on healthy living. Nevertheless, not all interviewed health care professionals could indentify who is the physical therapist, occupational therapist, trainer or masseur.

Correspondence to: eaevutis@gmail.com

Gauta 2017-03-27 